\title{
New proboscidean fossils from Middle Siwaliks of Haritalyangar area, Himachal Pradesh, India
}

\author{
Anek R. Sankhyan and Olivier Chavasseau
}

\begin{abstract}
We report here a number of dental fossil remains of proboscideans from Haritalyangar area of the Middle Siwaliks in Bilaspur District of Himachal Pradesh, North India collected by the first author (ARS) in different field seasons, who has also mapped the fossil localities. Most of these fossil localities fall in the Upper Alternations with very little explored previously. We have assigned the fossils into three main genera, Stegolophodon, ?Stegodon and Choerolophodon, besides a fossil fragment belonging to either a Gomphotheriidae or an Amebelodontidae. The choerolophodontid conforms well to Choerolophodon corrugatus, a common taxon in the Middle Siwaliks. Stegolophodon is richly represented in the proboscidean fossil record of the area distinguished into two species, one small indeterminate (Stegolophodon. sp.) and a larger one (S. cf. stegodontoides), which is a well-known representative of the genus in the Middle Siwaliks elsewhere. The topmost layers of the Upper Alternations have yielded remains that may belong to a derived stegodontid, Stegodon. These proboscidean fossils document a late Miocene assemblage and allow a correlation between the Upper Alternations and the Dhok Pathan Formation of the Middle Siwaliks and speak on the palaeoecology.
\end{abstract}

Dr. Anek R. Sankhyan, Palaeo Research Society, IPH Colony, Ghumarwin, Himachal Pradesh- 174021, India. arsankhyan@gmail.com

Dr. Olivier Chavasseau, Laboratory Paleontology Evolution Paleoecosystems Paleoprimatology UMR CNRS 7262 PALEVOPRIM, Université de Poitiers, 6 rue Michel Brunet, 86073 Poitiers Cedex 9 France. olivier.chavasseau@univ-poitiers.fr

Keywords: Stegolophodon cf. stegodontoides; Stegodon; Choerolophodon; Lower Alternations; Upper Alternations

Submission: 20 December 2017 Acceptance: 13 April 2018

Sankhyan, Anek R. and Chavasseau, Olivier. 2018. New proboscidean fossils from Middle Siwaliks of Haritalyangar area, Himachal Pradesh, India. Palaeontologia Electronica 21.1.15A 1-12. https://doi.org/10.26879/844

palaeo-electronica.org/content/2018/2200-haritalyangar-proboscideans

Copyright: April 2018 Society of Vertebrate Paleontology.

This is an open access article distributed under the terms of the Creative Commons Attribution License, which permits unrestricted use, distribution, and reproduction in any medium, provided the original author and source are credited.

creativecommons.org/licenses/by/4.0/ 


\section{INTRODUCTION}

Since the early Tertiary, the proboscideans have represented a major group of large herbivores in the mammalian communities. Three main phases of diversification occurred in the evolutionary history of this group (Shoshani and Tassy, 1996): the diversification of primitive proboscideans during the Paleogene in Afro-Arabia; the radiation of the Elephantimorpha during the early Miocene and the diversification of the Elephantidae and Stegodontidae (sometimes regrouped in the taxon Elephantida) during the Miocene. The elephantimorphs, which are closely related to the African Early Oligocene proboscidean Phiomia, are composed of several families (Gomphotheriidae, Choerolophodontidae, Amebelodontidae, Mammutidae) and characterized by a complexification of molar cusp pattern (trefoil pattern), the presence of a horizontal tooth replacement and a peculiar arrangement of tusk dentine ("guillochage pattern" or Schreger lines). The elephantimorphs represent the first offshoot of proboscideans that dispersed to Eurasia and diversifed in the Early Miocene. The Elephantidae and the Stegodontidae diversified most spectacularly in the Miocene of Africa and Asia, respectively. The representatives of these families convergently acquired highly-complex molars dedicated to antero-posterior mastication of food, shortened mandibles with loss of lower tusks, and high and largely-pneumatized skulls. Because they are recorded in most of the Neogene period, the sediments of the Siwaliks of India and Pakistan have long contributed to the documentation of elephantimorph, elephantid and stegodontid evolution in Southern Asia (e.g., Lydekker, 1880). Successive works on Siwalik proboscideans have revealed a rich paleodiversity of this group (e.g., Tassy, 1983a-c) and giving precious information about the evolution and diversification of Asian Neogene proboscideans.

The fluvial sediments of the Siwalik Group are exposed along the southern Himalayan foothills covering a great distance of about 2,400 km between river Indus in the west and the river Irrawaddy in the east comprising of over $7 \mathrm{~km}$ thick Himalayan wash-out molasses, spanning a great period of over 15 million years from early Miocene to Middle Pleistocene. The Potwar segment of the Siwaliks is the widest and has yielded the richest mammalian and hominoid fossil remains (e.g., Pilbeam et al., 1977a, b, 1980, Barry et al., 2002), followed by Haritalyangar and Ramnagar (J\&K) noted for late Miocene hominoid Sivapithecus, Gigantopithecus (=Indopithecus) and Krishnapithecus
(Simons and Chopra, 1969; Chopra and Kaul, 1978; Sankhyan et al., 2017; Pillans et al., 2005) besides mammalian faunal assemblages, and recently a rare Chameleon from the hominoid site (Sankhyan and Čerňanský, 2016). The proboscidean fossils, however, are sparingly reported from the Haritalyangar area. This study, therefore, makes a significant contribution to the late Miocene proboscideans by reporting rare dental fossils of three taxa, Choerolophodon, Stegolophodon and Stegodon from the localities exposed in the east of Haritalyangar at Lehri Sarail, Karan, Ladhyani, Kherin, Badon, Dholkhana, Bhapral, Barog and Bela (Figure 1). These have been grouped under "Upper Alternations" = Dhok Pathan Formation. Scholars visiting Haritalyangar have paid little attention to these localities and generally confined themselves to the hominoid rich Lower Alternations at Haritalyangar proper.

Prasad (1968) did collect some faunal remains from the Upper Alternation and noted Tatrot-like fauna affinities. Finding scope of doctoral research in the Upper Alternations, the first author (ARS) intensively explored this area during 1979-1985 and later intermittently during his personal field trips to his hometown and made rich collections of diverse mammalian remains and mapped their localities. So far he could only report the late occurrence of Sivapithecus (Sankhyan, 1985) and transgression of Dorcatherium nagrii (Sankhyan, 1991) in the Upper Alternations, pending study of the other fauna, such as proboscideans reported here.

A very recent review (Nanda et al., 2017) noted paucity of fauna and no proboscidean in the Upper Alternations (they called Ladhyani Formation). As such, the present report holds significance.

\section{MATERIALS AND METHODS}

The studied specimens were collected from the localities falling under Karan-Ladhyani-KherinBadon and Bhapral villages, located 3 to $5 \mathrm{~km}$ east of Haritalyangar, District Bilaspur, Himachal Pradesh, North India. One of us (ARS) has identified and completed a detailed mapping of 28 fossil localities falling between the Makkan Khad in the west and the Sir Khad in the east. Among these, 12 proboscidean-bearing localities have been identified (Figure 1). The proboscidean dental fossils under reporting were properly cleaned, washed and prepared in the laboratory. The specimens are measured with digital calipers to the precision of 


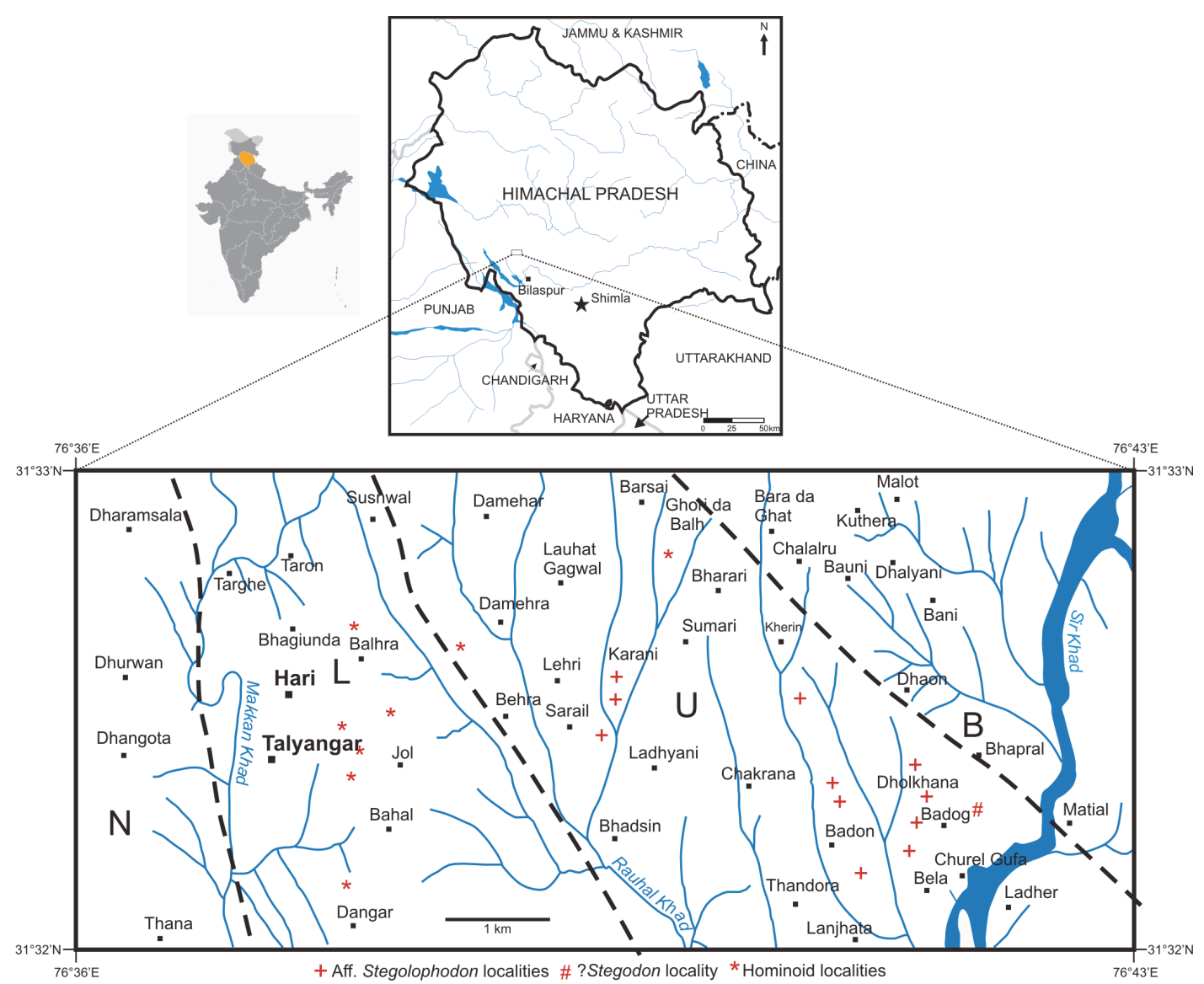

FIGURE 1. Map of the Haritalyangar area showing the fossiliferous localities of the hominoids and proboscideans. N: Nahan Formation (=equivalent to the Chinji Formation of the Siwaliks of Pakistan). L:'Lower Alternations' (=roughly equivalent to the Nagri Formation of the Siwaliks of Pakistan). U: 'Upper Alternations' (=Dhok Pathan Formation of the Siwaliks of Pakistan), B= Boulder Conglomerate. Dashed lines: limits between the formations (modified after Johnson et al., 1983).

$0.01 \mathrm{~mm}$. The metric details are presented in Table 1.

\section{Stratigraphy and Palaeomagnetism of the Haritalyangar Series}

The total section at Haritalyangar is 1600-m thick consisting of fluvially deposited alternating layers of claystone and fine-grained sandstone that accumulated in a gently subsiding foreland basin. Coarse-grained sediments and clasts are rare in the section, suggesting prolonged aggradation under an effective weathering regime. The presence of carbonate nodules and the sparse representation of lateritic ironstone suggest a seasonally wet sub-humid to semi-arid environment. The depositional environments include sandy channels, silty levees, clay flood plains and clay back swamps. The presence of thick paleosols above and within the claystone units indicates that the soils developed during short intervals of non-depo- sition on the levees and longer intervals of desiccation on the floodplains. Magnetostratigraphy of the Haritalyangar section is based on measured specimens from 64 sites reported by Johnson et al. (1983), supplemented by additional data of Brozovic and Burbank (2000) and Pillans et al. (2005). The preferred magnetic polarity correlation of Pillans et al. (2005) indicates an age for the section comprised between 11 and 8 Ma with a hominoidbearing part of the section dated from ca. 9.2 to 8.6 Ma.

However, all Proboscidean localities reported here fall under the Upper Alternations (=Dhok Pathan Formation). The lithostratigraphy of these localities is similar to that of the Haritalyangar Section, i.e., the multistory of the mudstones/clays alternating with the sandstones, with some difference that the mudstones become a lighter pink hue and are more extensive compared to the sandstones, which gradually become coarser and cal- 
TABLE 1. The locality-wise distribution of the proboscidean dental fossil findings recovered by ARS from the east of Haritalyangar along with their metrical details (in $\mathrm{mm}$ ). $\mathrm{L}=$ maximum antero-posterior length, $\mathrm{W}=$ maximum transverse diameter, $\mathrm{H}=$ maximum height of crown, ET= Enamel thickness. Localities: LOC-2: Karan East-Kutla- (Bhanwal)/Ladhyani Cho; LOC 2a: Karan-Ladhyani Cho; LOC-5: Kherin West; LOC-8: Badon North; LOC-12: Barog East Upper; LOC-14: Barog S-Bela N (Cap Ridge); LOC-16: Badon SE.

\begin{tabular}{|c|c|c|c|c|c|c|c|}
\hline $\begin{array}{l}\text { Catalogue } \\
\text { number }\end{array}$ & Locality & Tooth locus & Taxon & $\mathbf{L}$ & $\mathbf{W}$ & H & ET \\
\hline HTA-175 & LOC 2a & Right M3/ & Stegolophodon cf. stegodontoides & $\sim 180$ & 103 & 33 & 12 \\
\hline HTA-32 & LOC-2 & Left P/4 & aff. Stegolophodon & 43 & 38 & 19 & 5 \\
\hline HTA-41 & LOC-5 & Left P/4 & aff. Stegolophodon & 48 & 37 & - & 4 \\
\hline HTA-99 & LOC-14 & Left P/4 & aff. Stegolophodon & 42.5 & 29 & - & 5 \\
\hline HTA-115 & LOC-16 & Right M/3 & aff. Stegolophodon & $>140$ & 67 & 50 & 6.5 \\
\hline HTA-115a & LOC-16 & Right dP/3 & aff. Stegolophodon & 45.5 & 36 & 17 & 5 \\
\hline HTA-92 & LOC-12 & Right $\mathrm{M} 1 /$ or $\mathrm{M} 2 /$ & ?Stegodon & $>93$ & 82 & 32.5 & 5 \\
\hline HTA-46b & LOC-8 & Right M2/ & Choerolophodon corrugatus & 47 & 79 & 21 & 7 \\
\hline HTA-33 & LOC-2 & Left M/3 & $\begin{array}{l}\text { Gomphotheriidae/Amebelodontidae Gen. } \\
\text { et sp. Indet. }\end{array}$ & $>57.5$ & 51 & 23 & 5 \\
\hline
\end{tabular}

careous white in the upper layers visible between Kherin and Bhapral. The fauna of the Upper Alternations is little known and was initially viewed as corresponding to that of the Pliocene Tatrot Formation by Prasad (1968). The present work is therefore very significant to assess the age and affinities of this fauna. Specimens are housed in the Palaeo Museum of the Palaeo Research Society (Regd.) at Ghumarwin.

\section{SYSTEMATIC PALAEONTOLOGY}

Order PROBOSCIDEA Illiger, 1811 Suborder ELEPHANTIFORMES Tassy, 1988

Family STEGODONTIDAE Osborn, 1918

Genus Stegolophodon Schlesinger, 1917

Stegolophodon cf. stegodontoides Pilgrim, 1913

Figures 2.1 and 2.2

Lectotype. AM 86 (IM), right M3/

Type Locality. Lehri (Pakistan), Dhok Pathan Fm. (Middle Siwaliks).

Material. HTA-175 right upper M3

Description. HTA-175 is a right upper third molar with a slight flat lingual border and a convex buccal with more accentuated flexus between the lophs. The crown is low and convex in lateral perspective. HTA-175 is the largest among the molars reported here. It has suffered damage both at the posterior and anterior end. The posterior root $(121 \times 65 \mathrm{~mm})$ is fully preserved with three ribs and tapers backward. The remnants of two anterior and two middle roots are also preserved. The specimen is, however, complete in outline and enables estimation of the total number of lophs in the molar, which are five besides a talon. The lacking outer enamel rims of the first and second lophs indicate that they were completely and heavily worn. The posterior half of the third loph is well preserved, and its pretrite and posttrite cones are completely merged with the mesoconelets. It separates widely from the worn and damaged anterior half, exposing a wider transverse dentine cavity. The fourth loph is the most complete loph with presence of four blunt cusps of equal size and closely packed presenting exposed dentine on the pretrite mesoconelet and posttrite half-loph. The median and lateral sulci between the lophs are shallow. The prettrite main cusp is shifted distally relative to other cusps. There is a faint anterior bulge and a larger posterior bulge on the pretrite mesoconelet caused by the fusion of the mesoconelet with an anterior and a posterior central conule. A thick pretrite cingulum is present and tiny cingular cuspules are present between the third and fourth lophs. The fifth loph is preserved in its posttrite half. Its cusps are similar to those of the fourth loph but only little worn such that the dentine is nearly not exposed. The prettrite half-loph is mostly broken but its mesoconelet is half preserved and unworn. The talon loph is almost broken especially on the lingual side, though its posterior half is preserved buccally. A cingular shelf/bump runs across the posterior aspect of the talon.

\section{Discussion}

In India and Pakistan, the genus Stegolophodon has been reported from the Lower Siwaliks (Chinji Formation) and the Middle Siwaliks (Dhok Pathan Formation). However, the taxonomy of the genus is particularly problematic due to the lack of 

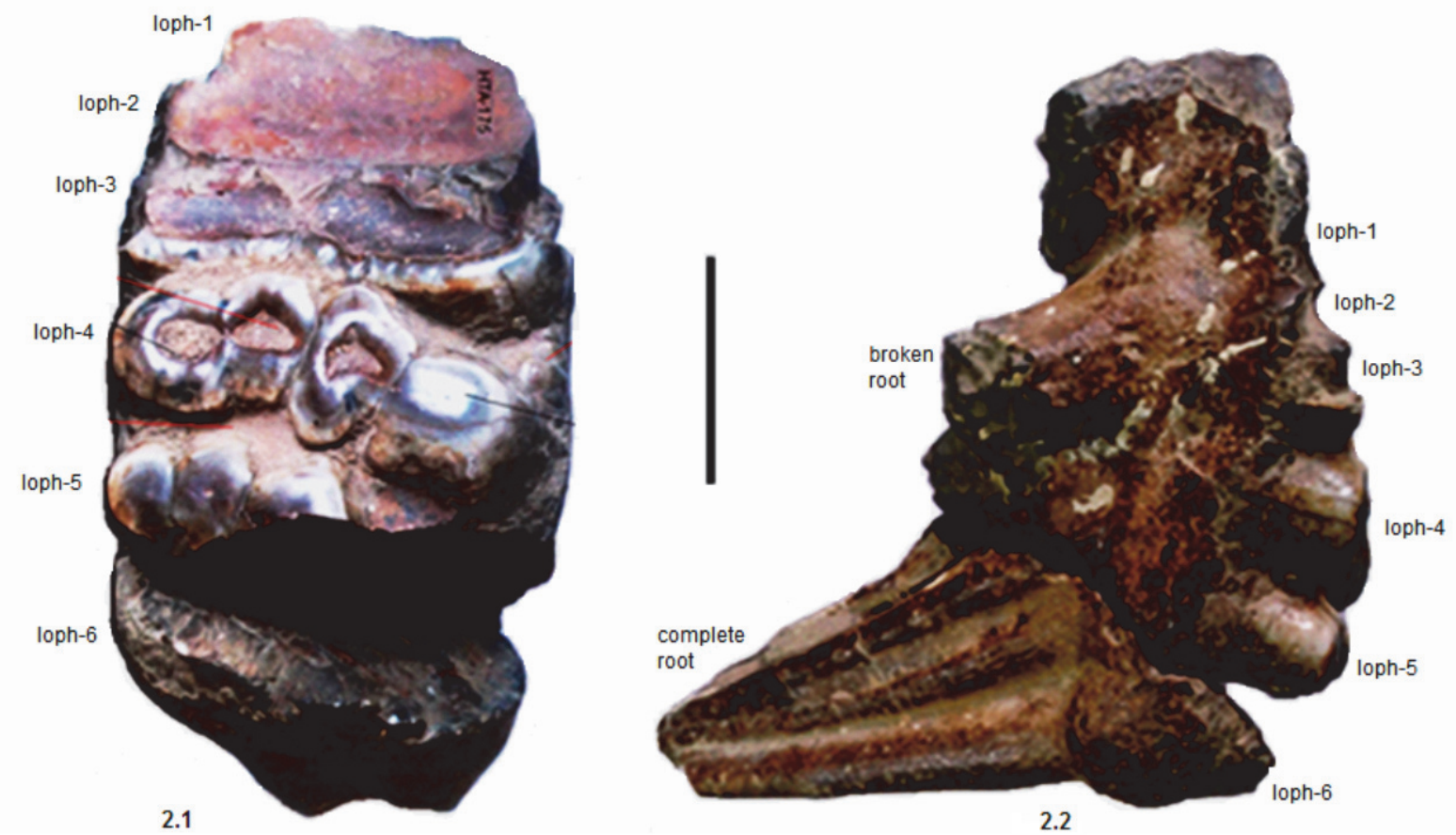

FIGURE 2. HTA 175, right $\mathrm{M}^{3}$ of Stegolophodon cf. stegodontoides. 2.1: occlusal view. 2.2: buccal view. Scale bar equals $5 \mathrm{~cm}$.

stratigraphic position of the specimens discovered in the nineteenth and early twentieth century in Southern Asia on which several species have been named and also by the lack of individuals bearing both upper and lower dentitions. This complicated taxonomic status renders a species-level identification very delicate. In his revision of the Siwalik proboscideans from Pakistan, Tassy (1983c) only recognizes two taxa: Stegolophodon cf. stegodontoides in the Dhok Pathan Formation (known range 10-7 Ma) and S. progressus from the Chinji formation (approximate range: $14-11 \mathrm{Ma}$ ). In a recent revision of Siwalik stegodontids, Johnston and Sanders (2017) considered that the main stegodontid taxon of the Dhok Pathan Formation was Stegodon stegodontoides identified between 9.4 and 7.2 in their sample. HTA-175 is a large-sized molar possessing cusps that are massive, rectangular at their base and low. These features are characteristic of S. cf. stegodontoides according to Tassy (1983c). HTA-175 is also in the same range of size as specimens of $S$. cf. stegodontoides, which often display similarly to it-a distal shift of the pretrite main cone as well as anterior and posterior bulges on the pretrite mesoconelets caused by the fusion with anterior/posterior central conules. Hence, it is most likely that the taxon S. cf. stegodontoides is represented in our material with HTA-175.

\section{aff. Stegolophodon}

Figures 3-4

Material. HTA-115 right M/3 (Figure 3), HTA-32, HTA-41, HTA-99: all left mandibular P/4; HTA115a, left dP3/ (Figure 4)

\section{Molars}

Description. HTA-115 was collected in two parts in two different field seasons, which, when examined in the laboratory, perfectly fitted with each other and therefore jointed together. This specimen is a subcomplete right lower third molar showing typical slender proportions, lingual concavity and buccal convexity and preserving four complete lophids 1 to 4 and a partial lophid 5 . The posterior half of the lophid 5 and the talonid have been broken away. The cusps are nipple-like in shape and show anterior inclination. They show no trace of wear, which indicates together with the absence of roots that this tooth was most likely a germ. The enamel is not very thick $(6.5 \mathrm{~mm})$. All lophids are transverse or slightly arching, made of two main cones and two mesoconelets. The mesoconelets are smaller and lower than the pretrite and posttrite main cones. The main cones are pointing medially, giv- 


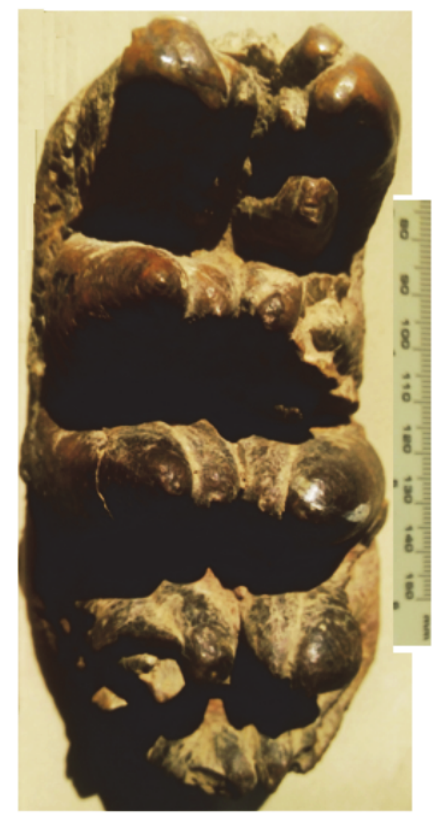

3.1

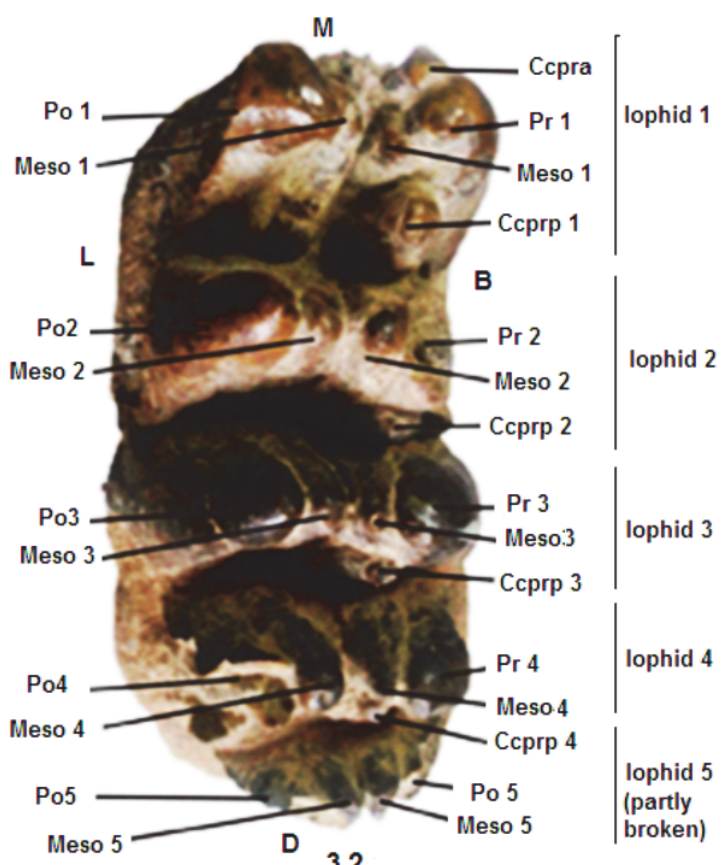

3.2

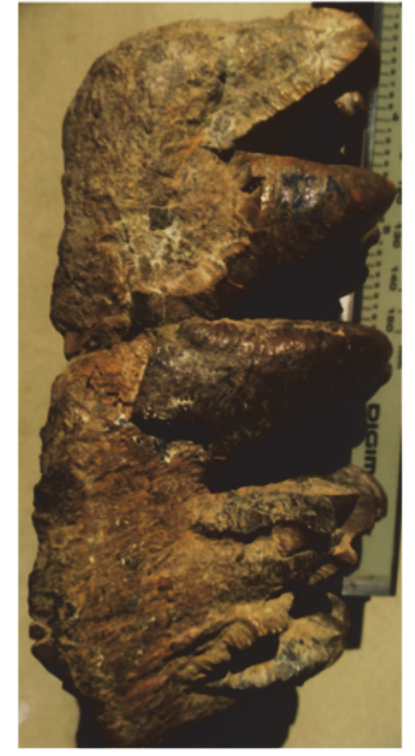

3.3

FIGURE 3. HTA-115, right $\mathrm{M}_{3}$ of aff. Stegolophodon sp. 3.1: occlusal view. 3.2: interpreted occlusal view. 3.3: buccal view. Scale bar equals $1 \mathrm{~cm}$. Dental nomenclature and abbreviations follows Tassy (1995): Meso= mesoconelet. Pr= pretrite main cone. $\mathrm{Po}=$ posttrite main cone. $\mathrm{Ccprp}=$ posterior pretrite central conule. Ccpra: anterior preprite central conule.

ing a strong inclination to the lateral walls of the lophids. Posterior central conules (Ccprp) are present on all the four valleys, and they diminish in size distally, being a smallest accessory cusp on lophid 4. The valleys are wide and not interrupted by the central cusps. An anterior central cusp is present only on lophid 1 . The central axial sulcus is visible but narrow and straight following the alignment of the cusps.

Remarks. The loph formula of HTA-115 indicates that this tooth belongs to a tetralophodont proboscidean. HTA-115 possesses several characteristic morphological traits of the stegodontids such as the transverse lophs, the opened valleys and the absence of pretrite trefoils due to the loss or reduction of central conules, and the relatively shallow central sulcus. However, the main cones are larger than the mesoconelets on HTA-115. This condition, plesiomorphous, is present in the dental variability of stegodontids but is not the most common in this family in which mesoconelets and main cones are generally similar in size. Contrariwise, unequal size between mesoconelets and main cones occurs more frequently in gomphotheres. Considering the morphology of HTA-115, we consider more likely that is represents a stegodontid with slightly smaller mesoconelets rather than a tetralophodont gomphothere, the latter identification implying the simultaneous variation of several features: loss of pretrite trefoils by a loss of anterior central conules 2-4 and a reduction of posterior central conules, enlargement and posterior shift of the mesoconelets. Because it retains primitive stegodontid features (reduced number of lophs, presence of central conules, small number of mesoconelets) we attribute HTA-115 to the plesiomorphous genus Stegolophodon. Smaller tooth dimensions, more rounded shape of the cusps and thinner enamel thickness distinguish this specimen from another molar HTA-175 attributed to the taxon S. cf. stegodontoides. The tooth dimensions of HTA-115 also do not match the Dhok Pathan specimens attributed to $S$. cf. stegodontoides by Tassy (1983c), the latter specimen being much larger. Thus, this specimen remains identified at the generic level.

\section{Premolars}

Lower $\mathbf{P}_{4} \mathbf{s}$. All of them display two lophids and a talonid. The anterior lophids bear on each tooth two cusps, the buccal one (protoconid) being larger. The posterior lophids are much wider, transversely oriented and possess two mesoconelets. The talonids are well developed with two or three 


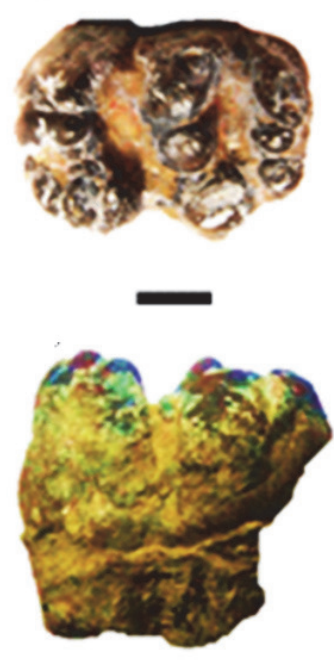

4.1

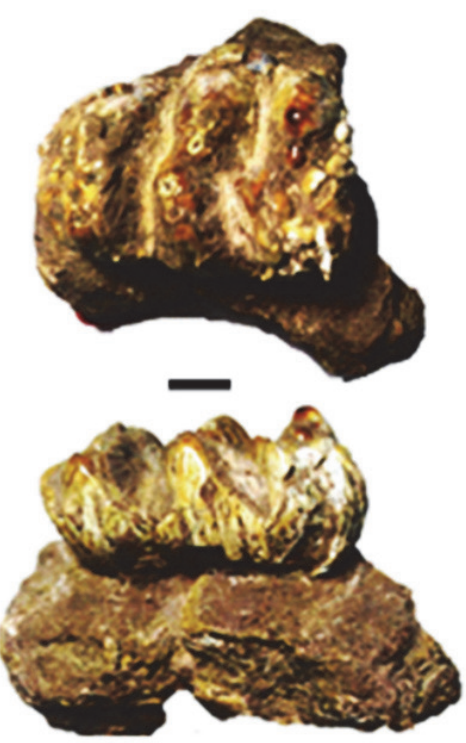

4.2
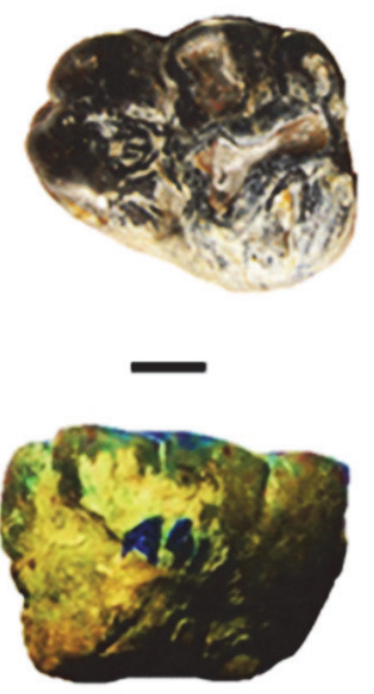

4.3
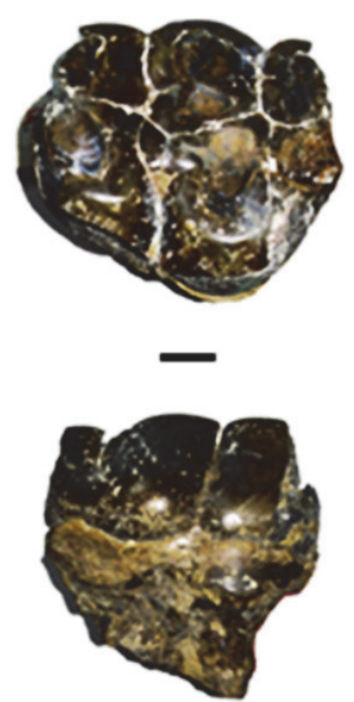

4.4

FIGURE 4. Aff. Stegolophodon premolars in occlusal (upper row) and buccal (bottom row) views: 4.1. HTA-99 left P/4; 4.2 HTA-115a left dP/3; 4.3: HTA-41, left P/4; 4.4 HTA-32, left P/4. Scale bars: $1 \mathrm{~cm}$.

cusps transversely oriented. A tiny median cusp is visible in the interlophid valley on HTA-32. On HTA41 , the anterior lophid is narrower relative to the posterior lophid than on the two other $\mathrm{P}_{4} \mathrm{~s}$.

Left dP3/ (Figure 4.2: HTA115a). It preserves complete, little worn three ridges (lophs) inclined anteriorly and a talon. The tooth is very low-crowned (Table 1), narrow anteriorly and becomes wider posteriorly. Loph 3 , slightly damaged buccally, was likely as wide as loph 2. A strong cingular shelf is present on the mesial side of the tooth. A buccal cingulum is also present at least around lophs 1 and 2. All lophs are made of two main cones and two or three mesoconelets. The mesoconelets are close in size with pretrite main cones but smaller than the posttrite main cones, which are more inflated. The mesoconelets are placed more mesially than the main cones rendering them $\mathrm{V}$-shaped, and the posttrite half-lophs are distally shifted relative to the pretrite ones. The central axial sulcus is very narrow but distinct on lophs 2 and 3 . The valleys are wide. A single tiny anterior bulge (=anterior central conule) is present on loph 2. The talon is composed of about four cusps. The enamel is rugose on the lingual aspects of the lophs.

Remarks. The three premolars HTA-41, HTA-32 and HTA-99 match well with the stegodontid genus Stegolophodon (see for example Chavasseau et al., 2009) in having low crowns bearing second lophids with four cusps including enlarged mesoconelets, second lophids much wider than the first lophids and a thick talonid composed of two or three large cusps. In comparison, tetralophodont gomphotheres have second lophids as wide as first lophids.

The dP3/ (HTA-115a). It belongs to a tetralophodont proboscidean according to its three lophs. It is tentatively identified as aff. Stegolophodon according to the markedly low crown and the simple morphology due to the nearly complete reduction of the central conules. These features have been pointed out by Tassy (1983) on a dP3/ of Stegolophodon cf. stegodontoides (GSP 4595) from the late Miocene of Pakistan and used to distinguish them from $\mathrm{dP} 3 \mathrm{~s} /$ of tetralophodont gomphotheres, which bear higher crown and several accessory cusps in the valleys. HTA-115a is proportionally lower-crowned than GSP 4595 (height index of 47 against 57) and also shares with this specimen the distal shift of the posttrite half-lophs. However, we cannot completely exclude that HTA-115a belongs to a tetralophodont gomphothere because it displays more arched lophs, a tiny median conule/ bulge on loph 2 and a narrower loph 1 than GSP 4595. These feature are also found among tetralophodont gomphotheres (e.g., Tassy 1983b).

The specimens regrouped under the name aff. Stegolophodon do not necessarily represent a 

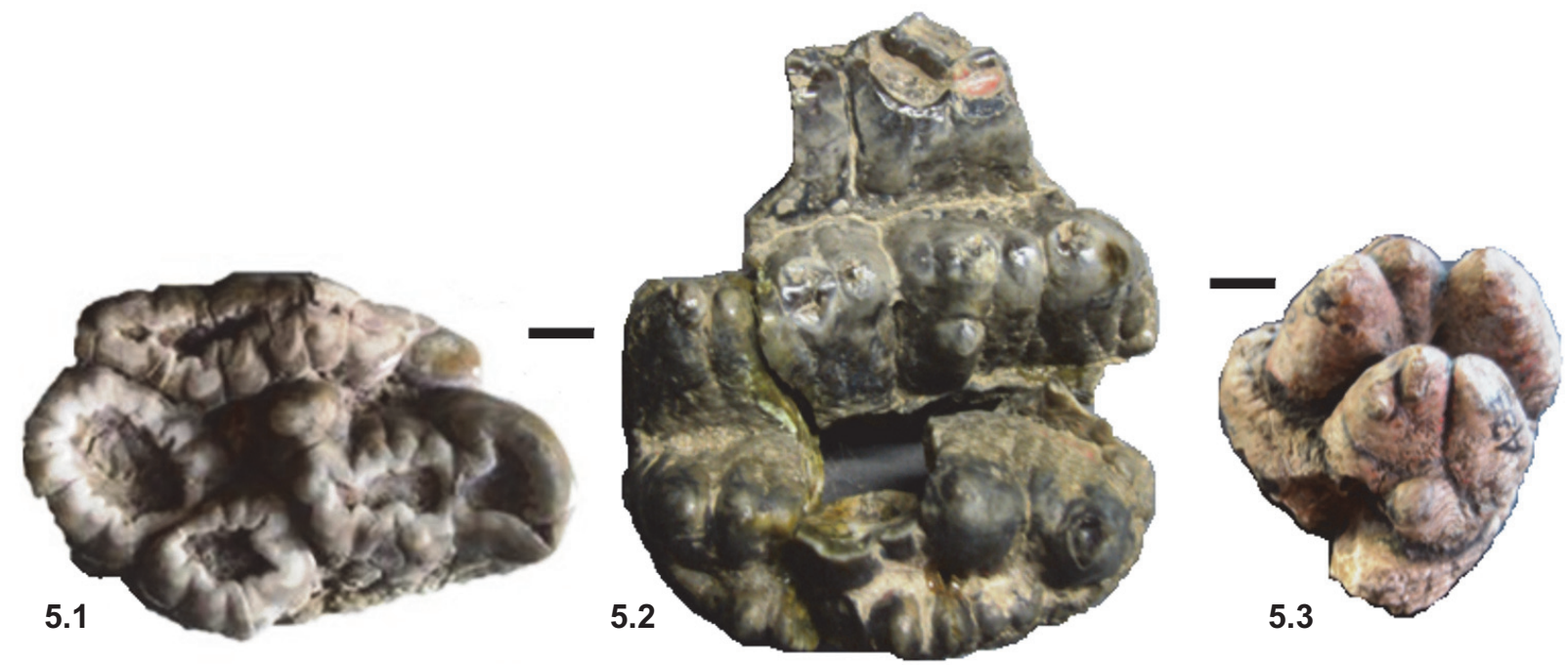

FIGURE 5. 5.1 HTA-46, right M2/ of Choerolophodon corrugatus. 5.2 HTA-92, right M1/ or M2/ of ?Stegodon sp.; 5.3 HTA-33, left M3 distal fragment of an indeterminate gomphothere or amebelodont. Scale bars $2 \mathrm{~cm}$.

single taxon. For instance, the three $\mathrm{P} / 4$ s present a certain degree of morphological variability in terms of enlargement of the second lophid and mesoconelets development: HTA-99 is notably narrower than the two other teeth and possesses a reduced pretrite mesoconelet. Hence, we are not sure that these isolated premolars belong to a single species. Moreover, the association between isolated molar, premolars and a deciduous premolar is tentative from a taxonomic point of view and should be best regarded as a morphological grouping.

\section{Genus ?Stegodon Falconer, 1857}

Figure 5.2

Material. HTA-92 posterior part of a right $\mathrm{M}^{1}$ or $\mathrm{M}^{2}$

\section{Description}

The specimen preserves parts of the three last lophs. The tooth is low-crowned, large-sized and wide. The most complete loph presents 8 small cusps separated by shallow sulci. The median sulcus is still noticeable, being slightly deeper than the other sulci. A small pretrite posterior central accessory cusp is also visible. The interloph valleys are wide, and the lophs are broad and uncompressed mesiodistally. The enamel is finely crenulated, especially on the lateral walls of the tooth.

Remarks. HTA-92 (Figure 5.2) corresponds with the morphology found in the genus Stegodon, in which the lophs are broad and made of numerous small cusps separated by shallow grooves. The reduction of the depth of the median sulcus and the finely crenulated enamel observed on HTA-92 are also common features in Stegodon. The presence of small central cusps or bulges on the molars of Stegodon is infrequent but occurs occasionally in this genus.

Stegodon is known in Southern Asia from the late Miocene to the Pleistocene. The retention of wide valleys, relatively thick enamel (for a Stegodon) and the conservation of a still visible median sulcus demonstrates that HTA-92 does not belong to a very advanced representative of the genus, these taxa being characterized by a thin enamel, a higher loph frequency and the absence of a marked median sulcus. The morphology of HTA-92 rather conforms to those of the Mio-Pliocene representatives of the genus.

Because the specimen is very fragmentary, it is also possible that HTA-92 represents a specimen of Stegolophodon in which accessory subdivision of the mesoconelets and main cones occurred. This tendency of cusp subdivision is not uncommon on posterior lophs of Stegolophodon and is difficult to evaluate because anterior lophs are missing or worn. More material would be needed to confirm the presence of Stegodon in the 'Upper Alternations'.

Family Choerolophodontidae Gaziry, 1976

Genus Choerolophodon Schlesinger, 1917

Choerolophodon corrugatus Pilgrim, 1913

Figure 5.1

Holotype. $A 98=W 3 / 16$, IM right mandible with $M / 2$ and $M / 3$, Calcutta, figured by Lydekker (1880:plate 
35 , figure 4 , plate 36 , figure I) and Osborn (1936:658, figure 626). Mandible fragment with symphysis and the right horizontal branch with broken $\mathrm{m} 2$ and m3. PUPC Zoology Department, University of the Punjab, Lahore.

Type locality. Hasnot (Pakistan) (Abbas et al. in press)

Known stratigraphic and temporal range. Chinji, Nagri and Dhok Pathan Formations (late Middle Miocene to late Miocene; ca.13.5-6.5 Ma according to Patnaik, 2013).

Material. HTA-46b (Figure 5.1) is a distal fragment of a right $\mathrm{M} 2$ /

\section{Description}

HTA-46b represents the last loph and the talon of an upper intermediate molar (M1/ or M2/). The specimen presents a markedly crenulated enamel and non-confluent wear between the cusps due to deep central sulci. The uniquely-preserved loph displays two main cones, a mesially shifted pretrite mesoconelet and one or two posttrite mesoconelets. A small posttrite posterior conule is also present. The talon is wide, transversely oriented, made of about seven cusps and delimited from the loph by a deep pretrite sulcus and the posterior valley.

Remarks. The specimen presents several morphological characteristics of choerolophodonts such as the crenulated enamel, the important depth of the sulci causing non-confluent wear between the cusps, and the choerodonty noticeable here by the presence of a posterior posttrite conule. In the Siwaliks, all the choerolophodontids are attributed to the genus Choerolophodon. This genus has been recovered in the Lower Siwalik Kamlial Formation (Early Miocene, Choerolophodon sp.) as well as in the Chinji, Nagri and Dhok Pathan formations of Middle Siwaliks (middle to late Miocene) with the species Choerolophodon corrugatus.

We refer HTA-46b to the species C. corrugatus, the morphology of this specimen being identical to those of Middle Siwalik attributed to $C$ corrugatus, the size of the specimen (maximum breadth $=79 \mathrm{~mm}$ ) fitting well with the known range of upper $\mathrm{M} 2 / \mathrm{s}$ of $C$. corrugatus $(74-91 \mathrm{~mm}, \mathrm{~N}=6$; Tassy, 1983b). The stratigraphic position of the specimen is also consistent with this identification, C. corrugatus being mostly recovered from the Dhok Pathan formations layers dated between 8.5 and $6 \mathrm{Ma}$ (Tassy, 1983b) where it represents the dominant proboscidean taxon.
HTA-92 was discovered from Locality 12 (Barog East Upper) in higher stratigraphic layers of the Dhok Pathan Formation, believed to be correlative to the Tatrot Formation by Prasad (1968). In comparison, the HTA-115 molar and HTA115a premolar were recovered from Locality 16: down below in the South east of Badon, attributable to the Dhok Pathan Formation.

Family ?Gomphotheriidae or ?Amebelodontidae Gen. et sp. indet.

Figure 5.3

Material. HTA-33 distal part of a left M/3 recovered from LOC-2: Karan East-Kutla/ Ladhyani Choe, down in the Dhok Pathan Formation.

\section{Description}

This specimen is narrow and presents the two last lophids of an $M / 3$ and a talonid. The penultimate lophid possesses two large main cones and a single large pretrite mesoconelet that is mesially shifted relative to the main cones and bears a small anterior central conule placed against it. The last lophid is made of two large cusps. The talonid is composed of a single small distal cusp. A thick pretrite cingulid is visible.

Remarks. HTA-33 does not match well with the morphology of the Stegodontidae in the combined presence of a single mesoconelet and an anterior central conule on the penultimate lophid. Most generally, the stegodontids possess two mesoconelets on the last lophid, and anterior central conules are not frequent on distal lophids. The two-cusp last lophid is also not typical of stegodontids, which often show three of four cusps on this lophid. If the identification of HTA-33 as a Stegodontidae cannot be completely excluded considering the high variability of $\mathrm{M}_{3} \mathrm{~S}$ in proboscidean, the morphology of specimen best matches those of tetralophodont gomphotheres and amebelodonts whose representatives often possess narrow and lower $\mathrm{M}_{3} \mathrm{~s}$ terminated by two-cusp or three-cusp last lophids, and have more frequent accessory cusps in the posterior valleys of molars than the stegodontids. The taxomony of tetralophodont gomphotheres and amebelodonts in the Middle Siwaliks is complex, few taxa being well known and identified. Nevertheless, several representatives of these groups have been recognized in the fossil record in the Dhok Pathan Formation such as the controversial "Tetralophodon" punjabiensis which has been considered either as an amebelodont or a tetralophodont gomphothere. Hence, HTA-33 may plausibly belong to one of these poorly-known taxa. 


\section{DISCUSSION AND INFERENCES}

Considered all together, the recovered proboscidean specimens from the 'Upper Alternations' of the Haritalyangar area correspond to a late Miocene assemblage owing to the domination in the fauna of proboscideans having achieved the tetralophodont grade (at least two species of Stegolophodon and Stegodon) associated with Choerolophodon corrugatus. If the latter species has a long middle to late Miocene temporal range (13.5-6.5 Ma according to Patnaik, 2013), its association with two taxa of Stegolophodon including the species recognized as $S$. cf. stegodontoides by Tassy (1983c) from the late Miocene of the Dhok Pathan Formation indicates thus a late Miocene age. This datation is in agreement with the possible presence of the derived stegodontid genus Stegodon in the fauna. Stegodon is not recorded in Asia prior to the late Miocene and has been identified in the latest Miocene in the Siwaliks of Pakistan (e.g., Khan et al., 2013 for the Hasnot area). Tassy (1983c) considered that the co-occurrence of Choerolophodon corrugatus, Stegolophodon cf. stegodontoides and Paratetralophodon hasnotensis was the faunal signature for the proboscideans of the Dhok Pathan Formation in the Siwaliks of Pakistan. Two of these taxa have been recognized in the Upper Alternations, which have clear faunal similarity with the Dhok Pathan Formation and seem thus correlative with the late Miocene part of this Formation (complete temporal range of the formation=10.1-3.5 Ma according to Barry et al., 2002) rather than with the Pliocene Tatrot Formation as believed by Prasad (1968).

The correlation between the section at Haritalyangar and the sequence of the Potwar Plateau has long been a matter of debate. The lower part of the Haritalyangar $1600 \mathrm{~m}$ sequence, the Lower Alternations, has classically been correlated with the Nagri Fm. while the Upper Alternations has often been correlated with the Dhok Pathan Fm. (e.g., Pilgrim, 1913) but these correlations have been considered as tentative (e.g., Pilbeam et al., 1977a). Johnson et al. (1983) have proposed a paleomagnetic correlation of Haritalyangar series in which the sequence was ranging in age from ca. 11 to $6 \mathrm{Ma}$. This correlation was implying that only the lower part of the Lower Alternations was contemporaneous with the Nagri Fm. In this view, the hominoid-bearing interval of Haritalyangar being part of the Lower Alternations, was younger than the upper boundary of the Nagri Formation (9 Ma, according to Barry et al., 2002). An alternate hypothesis has been proposed by Pillans et al. (2005) based on an augmented paleomagnetic study. These authors have proposed a 11-8 Ma date for the whole section with a hominoid-bearing interval dated between ca. 9.2 and $8.6 \mathrm{Ma}$. This correlation involves faster sedimentation rates and implies that the Lower Alternations correspond well to the temporal range of the Nagri Formation, i.e. 11.2-9.0 Ma (Barry et al., 2002). Accordingly, the Upper Alternations would be older than ca. 8.6-8.0 Ma suggested by Johnson et al. (1983).

The possible presence of Stegodon in our new material from the Upper Alternations would be more in agreement with the correlation of Johnson et al. (1983) since this genus seems to be present in latest Miocene of the Potwar Plateau, and has never been documented as early as $8 \mathrm{Ma}$. Our Stegodon material is meagre to confirm its presence for biochronological information to fully test the competing paleomagnetic correlations of Haritalyangar. Nevertheless, it does corroborates with the recent conclusion of Johnston and Sanders (2017), which indicates earliest appearance of genus Stegodon in the later Middle Siwalik deposits. It also suggests continuity of forested habitats favorable for tsuch proboscidean species, and corroborates with the late occurrence of Sivapithecus in the younger Upper Alternation (Sankhyan, 1985).

\section{ACKNOWLEDGEMENTS}

The fossil material reported here is catalogued, housed and displayed along with other fossils and archaeological material in the Palaeo Museum of the Palaeo Research Society (Regd.) at Ghumarwin and accessible to scholars and public.

\section{REFERENCES}

Abbas S.G., Khan M.A., Babar M.A., Hanif, M. and Akhtar, M. In press. New materials of Choerolophodon (Proboscidea) from Dhok Pathan Formation of Siwaliks, Pakistan. Vertebrata PalAsiatica. 
Barry, J.C., Morgan, M.., Flynn,L. J., Pilbeam, D., Behrensmeyer, A.K., Mahmood Raza, S., Khan, I.A., Badgley, C., Hicks, J., and Kelley, J. 2002. Faunal and environmental change in the late Miocene Siwaliks of northern Pakistan. Paleobiology Memoirs, 3:1-72.

Brozovic, N. and Burbank, D.W. 2000. Dynamic fluvial systems and gravel progradation in the Himalayan foreland. Geological Society of America Bulletin, 112:394-412.

Chavasseau, O., Chaimanee,Y., Yamee, C., Tian, P., Rugbumrung, M., Marandat, B., and Jaeger, J.-J. 2009. New Proboscideans (Mammalia) from the middle Miocene of Thailand. Zoological Journal of the Linnean Society, 155:703-721.

Falconer, H. 1857. On the species of mastodon and elephant occurring in the fossil state in Great Britain. Part I. Mastodon. Quarterly Journal of the Geological Society of London, 13:307-360.

Gaziry, A.W. 1976. Jungtertiäre Mastodonten aus Anatolien (Türkei). Geologisches Jahrbuch Reihe B, 22:1-143

Illiger, C. 1811. Prodromus systematis mammalium et avium. C. Salfeld, Berlin.

Johnson, G.D., Opdyke, N.D., Tandon, S.K., and Nanda, A.C. 1983. The magnetic polarity stratigraphy of the Siwalik Group at Haritalyangar (India) and a new last appearance datum for Ramapithecus and Sivapithecus in Asia. Palaeogeography, Palaeoclimatology, Palaeoecology, 44:223-249.

Johnston, S.R. and Sanders, W.J. 2017. Age, affinity, and succession of stegodontid proboscideans from middle Miocene-late Pliocene formations of the Siwalik sequence in South Asia. Journal of Vertebrate Paleontology, Programs and Abstracts, 138-138.

Khan, M.A., Batool, A., Nayyer, A.Q., and Akhtar, M. 2013. Gazella lydekkeri (Cetartiodactyla: Ruminantia: Bovidae) from the Middle Siwaliks of Hasnot (late Miocene), Pakistan. Pakistan Journal of Zoology, 45:981-988.

Lydekker, R. 1880. Indian Tertiary and post-Tertiary Vertebrata. 5. Siwalik and Narbada Proboscidia. Palaeontologia Indica, 10:182-294.

Nanda, A.C., Sehgal, R.K., and Chauhan, P.R. 2017. Siwalik-age faunas from the Himalayan Foreland Basin of South Asia. Journal of Asian Earth Sciences. https://doi.org/10.1016/ j.jseaes.2017.10.035.

Osborn, H.F. 1918. A long-jawed mastodon skeleton from South Dakota and phylogeny of the Proboscidea. Bulletin of the Geological Society of America, 29:133-137.

Patnaik, R. 2013. Indian Neogene Siwalik mammalian biostratigraphy: an overview, p. 423-444. In Wang, X., Flynn, L.J., and Fortelius M. (eds.), Fossil Mammals of Asia. Neogene Biostratigraphy and Chronology. Columbia University Press, New York.

Pilbeam, D.R., Barry, J.C., Meyer, G.E., Shah, S. M.I., Pickford, M., Bishop, W.W., Thomas, H. and Jacobs, L.L. 1977a. Geology and palaeontology of Neogene strata of Pakistan. Nature, 270:684-689.

Pilbeam, D.R., Meyer, G.E., Badgley, C., Rose, M.D., Pickford, M., Behrensmeyer, A.K., and Shah, I. S.M. 1977b. New hominoid primates from Siwaliks of Pakistan and their bearing on hominoid evolution. Nature, 270:689-695.

Pilbeam, D.R., Rose, M.D., Badgley, C., and Lipschutz, B. 1980. Miocene hominoids from Pakistan. Postilla, 181:1-94.

Pilgrim, G.E. 1913. The correlation of the Siwaliks with mammal horizons of Europe. Records of the Geological Survey of India, 43:264-326.

Pillans, B., Williams, M., Cameron, D., Patnaik, R., Hogarth, J., Sahni, A., Sharma, J.C., Williams, F., and Bernor, R.L. 2005. Revised correlation of the Haritalyangar magnetostratigraphy, Indian Siwaliks: implication for the age of the Miocene hominoids Indopithecus and Sivapithecus, with a note on a new hominid tooth. Journal of Human Evolution, 48:507-515.

Prasad, K.N. 1968. The vertebrate fauna from the Siwalik beds of Haritalyangar, Himachal Pradesh, India. Memoirs of the Geological Survey of India: Palaeontologia Indica New Series, 39:1-79.

Sankhyan, A.R. 1985. Late occurrence of Sivapithecus from Indian Siwaliks. Journal of Human Evolution, 14:573-578.

Sankhyan, A.R. 1991. The first record of Dorcatherium nagrii (Tragulidae, Mammalia) from the Dhok Pathan Formation (Middle Siwaliks) of Haritalyangar area, Himachal Pradesh. Himalayan Geology, 12:91-97.

Sankhyan, A.R. and Čerňanský, A. 2016. A first possible chameleon from the late Miocene of India (the hominoid site of Haritalyangar): a tentative evidence for an Asian dispersal of chameleons. Science of Nature, 103:94-100. https://doi.org/10.1007/s00114-016-1419-3 
Sankhyan, A.R., Kelley, J., and Harrison, T. 2017. A highly derived pliopithecoid from the late Miocene of Haritalyangar, India. Journal of Human Evolution, 105:1-12. https://doi.org/

10.1016/j.jhevol.2017.01.010

Schlesinger, G. 1917. Die Mastodonten des K. K. naturhistorischen Hofmuseums. Morphologisch-phylogenetische Untersuchungen. Denkschriften des K.K. naturhistorischen Hofmuseums, Geologisch-Paläontologische Reihe, 1:1-230.

Sein, C. and Thein, T. 2008. New Materials of Stegolophodon (Proboscidea, Mammalia) from the Irrawaddy Formation, Myanmar. Universities Research Journal, 1:49-64.

Shoshani, J. and Tassy, P. 1996. The Proboscidea. Evolution and palaeoecology of elephants and their relatives. Oxford University Press, Oxford and New York.

Tassy, P. 1983a. Les Elephantoidea Miocènes du plateau du Potwar, Groupe de Siwalik, Pakistan. Première partie: introduction, cadre chronologique et géographie, mammutidés, amébélodontidés. Annales de Paléontologie, 69:99-136.

Tassy, P. 1983b. Les Elephantoidea Miocènes du plateau du Potwar, Groupe de Siwalik, Pakistan. Deuxième partie: Choerolophodontes et Gomphothères. Annales de Paléontologie, 69:235-297.

Tassy, P. 1983c. Les Elephantoidea Miocènes du plateau du Potwar, Groupe de Siwalik, Pakistan. Troisième partie: Stégodontidés, Eléphantoïdes indéterminés. Restes postcraniens. Conclusions. Annales de Paléontologie, 69:317-354.

Tassy, P. 1988. The classification of Proboscidea: how many cladistic classifications? Cladistics 4:43-57. 